1 The role of vegetation and large wood on the topographic characteristics of braided river systems

2

3 Luca Mao $^{1,2^{*}}$, Diego Ravazzolo ${ }^{3}$, Walter Bertoldi ${ }^{4}$

4

$5 \quad{ }^{1}$ School of Geography, University of Lincoln, Lincoln, UK

$6 \quad{ }^{2}$ Instituto de Geografia, Pontificia Universidad Católica de Chile, Santiago, Chile

$7 \quad{ }^{3}$ Faculty of Engineering, University of Auckland, Auckland, New Zealand

$8 \quad{ }^{4}$ Department of Civil, Environmental and Mechanical Engineering, University of Trento, Trento, Italy

$9 \quad$ *Corresponding author: Luca Mao (lumao@lincoln.ac.uk)

10

11 Abstract

12 Riparian vegetation and large wood play a crucial role in shaping rivers. On the one hand, vegetation tends to increase bank stability, reduce channel width and reduce the braiding index in gravel-bed rivers.

14 Conversely, large wood tends to increase channel dynamics and promote avulsions. The effects of 15 vegetation and large wood have been rarely simulated together in flume experiments. In this paper we present a series of experimental runs conducted in a large flume facility, using cylindrical wooden dowels and alfalfa seedlings to represent logs and vegetation, respectively, in order to investigate their role on determining the topographical nature of braided river systems. A terrestrial laser scanner was used to measure in detail the topography of the channels and bars, and distribution of the elevations and secondorder structure functions were used to explore the topography that large wood and vegetation imposed on the braided pattern in the flumes. Results show that vegetation reduced the braiding index and produced wider and deeper channels. The standard deviation of the bed elevations was higher than in flumes without vegetation. Large wood alone was not effective in changing the braiding index or the standard deviation of the elevations. When vegetation and large wood acted together in the flume, the braiding index reached a minimum value, and the skewness of the distribution of elevation increased, revealing shallower pools if compared with runs conducted with only vegetation.

29 The world's rivers are 7.56 million kilometers long and represent an area of 508,000 $\mathrm{km}^{2}$ (Lehner et al., 2011), being one of the most important elements that shape Earth's surface. Rivers are constantly 
changing as a result of complex interactions and feedbacks between processes related with the climate, hydrological and sediment regimes (Wohl et al., 2015), but also with the vegetation dynamics at the basin and riverine scales (Corenblit and Steiger, 2009; Eaton and Giles 2009; Pfeiffer et al., 2017). Several studies described the role of vegetation in determining Earth surface processes. Indeed, the effects of vegetation on river morphology was demonstrated in the field (Simon and Collison, 2002), experimentally (Tal and Paola, 2007, 2010; Braudrick et al., 2009; Bertoldi et al., 2015) as well as numerically (Murray and Paola, 2003). Gurnell et al. (2012) showed that the interactions between fluvial processes and riparian and aquatic vegetation could also affect the long-term evolutionary trajectories of rivers.

Vegetation, in terms of living plants, can exert an important geomorphic role even after being eroded from banks and hillslopes. Logs and pieces of large wood (LW) can indeed alter the morphology of rivers by deflecting the flow, accumulating sediments and scouring pools, and also favouring the formation of pioneering islands (Abbe and Montgomery, 1996, 2003; Braudrick and Grant, 2000). Both vegetation and large wood determine the shape and dynamics of rivers (Buffington and Montgomery, 1999; Brooks et al., 2003; O'Connor et al., 2003) as braided systems with islands, which are often the highest expression of ecosystem integrity within fluvial systems (Francis et al., 2009). However, vegetation and large wood seem to exert opposite roles in conditioning river morphology. Vegetation increases bank stability and thus reduces channel width and increases the mean channel depths, also reducing the number of channels per river cross section (i.e., the braiding index; Tal and Paola, 2010), and reducing avulsion rates (Ashmore, 2013). Instead, large wood tends to increase channel dynamics, and create anastomosing river patterns, with more and deeper pools, often creating pioneering islands. Sedell and Froggatt (1984) and Collins et al. (2002) compared relatively undisturbed systems with systems where large wood was removed. They reported that the channel pattern shifted from anastomosing to braiding or meandering with a simpler structure and a single, wider active channel. Only recently, experimental studies started to investigate the joint influence of vegetation and large wood on river morphology. Indeed, Bertoldi et al. (2015) showed that the inclusion of vegetation in the experiments changes wood dynamics, promoting the formation of larger and more stable wood jams, reinforcing their effect on river morphology.

The present paper explores the morphological role of both vegetation and large wood in braided rivers, especially in terms of topography. At a global scale, the appearance of vascular plants on Earth forced a progressive change in the shape of rivers from braided systems to meandering and island braided rivers 
(Gibling and Davies, 2012). At smaller scales, Dietrich and Perron (2006) investigated the topographic signature of life on Earth by interpreting landform proprieties such as channel width and sinuosity. Bertoldi et al. (2011) combined analysis of airborne LIDAR, air photographs and ground measurements analysed the topographic signature of vegetation development along the Tagliamento River in Italy, identifying significant associations between vegetation proprieties and reach morphology. This paper builds on the flume experiments presented by Bertoldi et al. $(2014,2015)$, and it takes advantage of detailed topographical surveys of the channels to assess the mutual effects of riparian vegetation and large wood in braided river systems by analysing the topography left by living plants and large wood using a physical modelling approach.

\section{Material and methods}

\subsection{Experimental setup and runs}

The experiments were conducted at the Total Environmental Simulator facility, a 6 m-wide, $11 \mathrm{~m}$-long flume at the University of Hull (UK). Three 1.7 m-wide parallel channels $(\mathrm{C} 1, \mathrm{C} 2$, and $\mathrm{C} 3$ ) were built inside the flume using concrete blocks, which were filled with homogeneous sand $\left(\mathrm{D}_{50}=0.73 \mathrm{~mm}\right)$ with a surface slope of $0.013 \mathrm{~m} \cdot \mathrm{m}^{-1}$ (Fig. 1). Water was supplied at the upstream end of each channel using submerged pumps with a steady discharge of $1.261 \cdot \mathrm{s}^{-1}$ (see Bertoldi et al., 2014, 2015 for a detailed description of the experimental runs).

At the beginning of the experiment, the flumes were operated with a steady flow and steady sediment supply. Sand was supplied using a sand feeder and a filtering crate was fitted in the downstream end of the flume to quantify the bedload rate. The sediment feeding rate of $1.9 \mathrm{~g} \cdot \mathrm{s}^{-1}$ was maintained for approximately $21 \mathrm{~h}$. This allowed quasi-equilibrium conditions to be obtained in terms of braided morphological patterns and sediment input/output $( \pm 15 \%)$. The experimental runs involving the use of only sand in the flumes are named S (Table 1; Fig. 1a).

After the topographical measurement for the runs $\mathrm{S}$ were taken (see later), the experiment continued with the feeding of large wood (sand and large wood runs SLW, Table 1; Fig. 1b). In-channel wood was reproduced using cylindrical $8 \mathrm{~cm}$-long wooden dowels, which were built to be shorter than the width of the single anabranches. A mixture of wooden dowels with and without cross-shaped root wads was used. Dowel and the root wad sizes were decided based on field data collected in the Tagliamento River (northeast Italy) as reported by Bertoldi et al. (2013). At the beginning of the run, logs were introduced 
from the upstream end of the flume channels every $15 \mathrm{~min}$ at rates of 60,120 , and $180 \operatorname{logs} \cdot \mathrm{h}^{-1}$ in $\mathrm{C} 1, \mathrm{C} 2$, and C3, respectively. After the first six hours, the wood input rate was reduced to 40, 80 and $120 \operatorname{logs} \cdot \mathrm{h}^{-1}$ in channels $\mathrm{C} 1, \mathrm{C} 2$ and $\mathrm{C} 3$, respectively (SLW runs, Table 1). The run was stopped after $18 \mathrm{~h}$ of log input when approximate equilibrium was reached (i.e., output equal the input rate of logs). During these runs, the sediment input was kept constant at $1.9 \mathrm{~g} \cdot \mathrm{s}^{-1}$. After the topographical measurement for the runs SLW were taken (see next session), the logs were manually removed from the surface of the channels in order to survey again the channels as S-LW (sand minus large wood, Table 1). The removal of wooden dowels was done very carefully, and a comparison of SLW and S-LW topography (see later Figs. 3 and 4) confirmed that this procedure had a negligible impact on the braiding pattern of the flume.

Further experimental runs were designed to explore the effects of vegetation alone, and then vegetation plus large wood on the braided pattern. After the in-channel logs were manually removed (S-LW runs), a new steady-state braided pattern was created in the flume channels using steady flow and sediment input rates as for the $\mathrm{S}$ runs. Then, alfalfa seeds (Medicago sativa) were mixed with dry sand and manually seeded in the three flume channels with a density of approximately $1 \mathrm{seed} \cdot \mathrm{cm}^{-2}$. A baseflow of $0.21 \cdot \mathrm{s}^{-1}$ was imposed to maintain flow in the channels without disturbing the channel bed, but removing seeds from the wetted channels, to avoid a complete mat of vegetation from growing in the flumes. Artificial illumination provided constant light and temperature of approximately $20^{\circ} \mathrm{C}$, which helped the establishment of the alfalfa seeds. After the seeding, a high flow $\left(1.261 \cdot \mathrm{s}^{-1}\right)$ was supplied to rework the channel morphology. Channel 1 was left to evolve with only the presence of vegetation (SV runs, Table 1, Fig. 1c). Otherwise, in channels 2 and $3 \operatorname{logs}$ were introduced at rates of 40 and $120 \operatorname{logs} \cdot \mathrm{h}^{-1}$, respectively (runs SVLW, Table 1, Fig. 1d). Similar to previously reported experiments (Tal and Paola, 2007, 2010; Clarke, 2014), alfalfa rapidly developed roots and stems up to $2 \mathrm{~cm}$ in length and up to $2 \mathrm{~mm}$ in diameter. For this reason, experiments were run for eight hours per day at the base flow, for a total of four weeks (120 h overall). To replicate the vegetation growing on floodplains and high bars in natural rivers, alfalfa was seeded every seven days (Table 1). As the experiments were longer because they included the use of vegetation, a series of four topographic measurements were taken (at 25\%, 50\%, 65\% and at the end of the duration of the runs; Table 1).

Reproducing fluvial environments in small facilities is challenging because of the need to scale both physical and ecological factors. Apart from the challenge of scaling fluvial processes associated with the sequence of events of different magnitude and frequency, additional issues arise when introducing 
121

122

123

124

125

126

127

128

129

130

131

132

133

134

135

136

137

138

139

140

141

142

143

144

145

146

147

148

149

vegetation, and indeed most flume studies involving vegetation tend to simplify plant geometry and biomechanical properties (Fernández et al., 2019). The proportionality between biotic and abiotic elements in eco-morphological experiments also must be considered and vegetation must be reduced in size to address space limitations (Green, 2014). Given the difficulty simultaneously scaling precisely the geometry of the river, large wood and vegetation, the experiments were not planned to scale a specific prototype but were rather designed to represent fluvial processes in a generic gravel-bed braided river (Paola et al., 2009). By doing so, we are simplifying several natural processes, and we are especially disregarding the effects of cohesive sediments in stabilizing the banks, the resprouting capacity of fresh LW, and the complex relationships between the occurrence of floods and the time needed for vegetation to colonize the floodplains. However, by simplifying the case to a generic braided gravel-bed river, we allow comparisons of competing processes (vegetation and LW) that are difficult to disentangle in natural environments. Although the aim was to study processes, the model was designed to allow the flume channels for being more than 10 times larger than the length of the wooden dowels as in large gravel-bed rivers, and the dowels were selected to be shorter than the width of single anabranches. Also, the designed log input rates assumed an uncongested transport regime (Ruiz-Villanueva et a., 2019), which is typical of ordinary flood events as those simulated in the flume. With the designed log input rates, the number of logs stored in the channels ranged between 70 to 200 logs in one width/length river reach, which resemble values measured in large multithread gravel-bed rivers (Bertoldi et al., 2014).

\subsection{Laser scanner surveys and ground point filtering}

The entire flume facility was surveyed with a Leica ScanStation2 Terrestrial Laser Scanner (TLS) at the end of each run, after the flumes had drained for a few hours. Overall, seven scans were analysed for each channel, one for the experiments using only sand (S), one for the experiments with sand and large wood (SLW), one for the channels with sand minus large wood (S-LW), and four for the runs with vegetation (SV) and vegetation plus large wood (SVLW), respectively (Table 1). On each survey, the TLS was placed on the four corners of the flume, and the scans were taken setting the resolution at a cell size of 1 $\mathrm{mm}$ at $7.5 \mathrm{~m}$ from the device. Six fixed targets were used to register and geo-reference each scan using Cyclone software (Cyra Technologies Inc.). To avoid areas with low point density around the edges of the flume, a $1.4 \mathrm{~m}$-wide, $6 \mathrm{~m}$-long area was selected for scanning all the flume channels. 
The filtering of the vegetation proved to be challenging because of the very dense canopy developed by

151 alfalfa plants, especially at the end of the runs (i.e., Fig. 1c and 1d). The filter, developed by Moretto

152 (2014), operated on three steps. The first gross filtering was conducted manually from the points cloud in

153 Cyclone, eliminating all points over the reasonable range of ground points. In a second step, the ground

154 points were extracted from the scans using a script developed in Matlab. The filter creates a reference

155 RGB (red, green and blue) triplet for an area with only sand and the RGB values of all points within the

156 scan were compared to the reference triplet. A point was removed if its RGB triplet diverged from the

157 reference by more than a user-selected percentage, which was identified through trial and error. The final

158 step was carried out by a geometrical filter, which was applied to delete the outlier points (Moretto,

159 2014). Finally, areas that were completely covered by dense vegetation with no true ground point visible

160 through the canopy, were assigned the same bed elevation as the previous DEM. Each filtered scan was

161 interpolated and a digital elevation model of the channels (DEM) with a cell size of $1 \mathrm{~mm}$ was created

162 using ArcMap (Esri's ArcGIS suite). Each DEM was detrended in the stream-wise direction using linear

163 interpolation, and finally the probability density functions (PDFs) of the bed elevations were extracted.

164

165

166

167

168

169

170

171

172

173

174

175

176

177

178

179

\subsection{Calculation of the statistical proprieties of the bed topography}

The mean, standard deviation, and skewness of the detrended DEMs were analysed to obtain descriptive statistics of the main characteristics of the frequency distribution of the elevations (PDFs) of the flumes.

The standard deviation of the bed surface $(\delta)$ is meaningful as it can be interpreted as the characteristic vertical roughness length scale of water-worked channel. The skewness $(S k)$ of the bed elevation represents the shape of the probability density functions in terms of asymmetry, and is expected to change as a function of vegetation cover (Bertoldi et al., 2011).

Additionally, a two-dimensional second-order structure function (or semivariogram) of the bed surface elevations was used to better assess the correlation between elevations at various spatial scales and different directions. Using a dimension of the sample of $1 \mathrm{x} 1 \mathrm{~m}$, structure functions were used to assess the spatial correlation in bed elevation at various distances in different directions. A second-order structure function $\gamma\left(1_{x}, l_{y}\right)$ of bed surface elevation $\mathrm{z}_{\mathrm{b}}(\mathrm{x}, \mathrm{y})$ was defined as an average-squared increment $\{\mathrm{Z}(\mathrm{x}+\mathrm{Ix}, \mathrm{y}+\mathrm{Iy})-\mathrm{Z}(\mathrm{x}, \mathrm{y})\}^{2}$. The two-dimensional structure function surfaces were derived for all the scans and they can be estimated from: 


$$
\begin{gathered}
\gamma\left(\mathrm{I}_{\mathrm{x}}, \mathrm{I}_{\mathrm{y}}\right)=\frac{1}{(\mathrm{~N}-\mathrm{n})(\mathrm{M}-\mathrm{m})} \\
\sum_{\mathrm{i}=1}^{\mathrm{N}-\mathrm{n}} \sum_{\mathrm{j}=1}^{\mathrm{M}-\mathrm{m}}\left\{\mathrm{z}\left(\mathrm{x}_{\mathrm{i}}+\mathrm{n} \delta \mathrm{x}, \mathrm{y}_{\mathrm{i}}+\mathrm{m} \delta \mathrm{y}\right)-\mathrm{z}\left(\mathrm{x}_{\mathrm{i}}, \mathrm{y}_{\mathrm{j}}\right)\right\}^{2}
\end{gathered}
$$

181

182 where $\mathrm{l}_{\mathrm{x}}=\mathrm{n} \delta_{\mathrm{x}}$ and $\mathrm{l}_{\mathrm{y}}=\mathrm{m} \delta_{\mathrm{y}}$ are spatial lags, $\delta_{\mathrm{x}}$ and $\delta_{\mathrm{y}}$ are the sampling intervals, and $\mathrm{N}$ and $\mathrm{M}$ are the total

183

184

185

186

187

188

189

190

191

192

193

194

195

196

197

198

199

200

201

202

203

204

205

206

207

208

number of measuring points of bed elevations in directions $\mathrm{x}$ and $\mathrm{y}$, respectively. For the special case of a homogeneous random field, as presented by Monin and Yaglom, (1975), Nikora et al. (1998) and Mao et al. (2011), the second- order structure function has the following relationship with the correlation function $\mathrm{R}\left(\mathrm{l}_{\mathrm{x}}, \mathrm{l}_{\mathrm{y}}\right)$ :

\section{Results}

\subsection{Channel morphology}

The number of channels per cross section (i.e., the braiding index, Bi) for the $\mathrm{S}$ experiments is consistent with what is reported in similar earlier experiments and is around 4.5 (Fig. 2). As previously reported by Bertoldi et al. $(2014,2015)$ for the same experiments, the braiding index decreased only slightly as a result of the addition of LW, and the flumes were still characterized by a dynamic braided system with multiple, narrow channels, irrespective of the rate of LW input. However, the progressive establishment of vegetation on the highest bars resulted in a marked morphological shift from braided to wandering (Fig. 2), with a reduction of the braiding index (from 4.5 to 2.5; Bertoldi et al., 2015).

Fig. 2 also shows a comparison of the channel width for the runs conducted using the different settings, presented as the ratio between the summed width of the active channels (w) and the overall width of the flume (W) at the end of each run, averaged over eight transects selected along the length of the flumes, and also in terms of average width of all active channels on the selected transects. In unvegetated channels, the addition of logs was not able to modify the planform morphology of the multithread pattern, and the relative width remained around a median value of 0.4 for S and SLW, and the average width of active channels was around $0.13 \mathrm{~m}$. The cross-wise space occupied by active channels and the average width of the channels decreased considerably in the runs where vegetation was progressively encroaching the flumes (SVLW of the $\mathrm{C} 2$ and C3), down to a median value of 0.25 for the relative width and with an average width of $0.07 \mathrm{~m}$. Interestingly, the concurrent morphological action of vegetation and added logs 
during the experiments SVLW was not effective in increasing the relative occupancy of active channels in

210 the cross sections (as the median value ranged around 0.25 ), but the average width of the active channels

211 increased to a median value of $0.1 \mathrm{~m}$. This reveals that wood jams are effective in increasing the average

212 width of the channels by diverting the flow towards the banks and increasing lateral erosion. Indeed, on

213 C3 (SVLW, Fig. 1d) two large wood jams caused flow diversion that stabilized the channel, reduced the

214 braiding index, and contributed to increase the average channel width.

215

\subsection{Statistical properties of the PDFs of the bed elevations}

217 Fig. 3 shows the PDFs of the different runs derived from the DEMs. The PDFs of the three unvegetated

218 flumes (S) are mostly similar in shape and distribution, suggesting a good deal of comparability in the surface distribution of elevations in the three parallel flumes subject to the same boundary conditions.

220 Also, the distributions are fairly similar for the experiments conducted with LW input, and also for the

221 flumes where logs were finally manually removed, suggesting that the wooden dowels are ineffective in

222

223

224

225

226

227

228

229

230

231

232

233

234

235

236

237

238

shaping the overall topography of the braided pattern. Vegetation progressively growing on the flume caused the PDFs to become broader, with a greater deviation of the values away from the zero-central value, meaning lower and higher extremes of elevations that suggest deeper scours and higher localized depositional areas within the flume (SV on C1, Fig. 3). On the SVLW runs, the addition of LW along with the vegetation growing on the channel caused the PDF to become broader, without noticeable differences if compared with the SV runs.

Descriptive statistics of the bed elevation PDFs such as standard deviation and skewness are shown in Fig. 4. The standard deviation of elevations represents the vertical topographic roughness of the braided morphology and is around $4 \mathrm{~mm}$. This is nearly an order of magnitude higher than the grain size of the sand used in the experiments, as it accounts for the typical morphological units of braided rivers, including high bars and the scoured channels. Interestingly, the addition of logs was not effective in changing the standard deviation of elevations as $\delta$ ranges between 3.5 and $4.5 \mathrm{~mm}$, and this is very consistent on the three parallel flume channels (Fig. 4a, b, and c). Vegetation growing on the flumes produced a progressive and marked increase of the standard deviation of elevation over time, and at the end of the run SV on $\mathrm{C} 1$ (Fig. 4a), the value of $\delta$ was around 8, two times higher than without vegetation.

On the flumes where logs and vegetation were acting together in shaping the morphology of the channels, the standard deviation of the bed elevations increased progressively over time too. However, during the 
third alfalfa seeding (SVLWc), in $\mathrm{C} 2$ we recorded a standard deviation comparable to the values measured at the end of the experiments in $\mathrm{C} 1$ and $\mathrm{C} 3$. Interestingly, there is no apparent difference in terms of $\delta$ between SV and SVLW on C3, despite the higher rate of LW input (120 logs $\cdot \mathrm{h}^{-1}$; Fig. 4c).

The shape of the PDFs was also captured using the skewness (Sk) index (Fig. 4d, e, and f). Skewness showed a less regular pattern than the standard deviation, with negative values fluctuating between -0.4 and -1.6. In the S runs, Sk was lowest in flume 1 (about -1, Fig. 4d) and higher in the other two flumes (about -0.5 , Fig. $4 \mathrm{e}$ and $\mathrm{f}$ ). The fact that a braided pattern shows negative values of skewness indicates that the longer tail of the PDF tends to lie on the lower elevations, suggesting that there are few concentrated spots with deep scours. These deep scours are arguably located at the confluences of the multiple anabranches of the braiding pattern, as shown in Fig. 5, and their presence is indeed consistent with the fact that on the S and SLW runs the braiding index is at its highest value. Riverbed configuration is reported in Fig. 5 for all the runs, where the lowest $10 \%$ of the points is highlighted in red. Deepest points are located in relatively small areas for the S and SLW runs, where they represent confluence and local scours. Through SV and SVLW runs the deepest points tend to join in elongated areas, representing the deeper main anabranch where most of the flow is concentrated.

The addition of LW had an opposite effect on the skewness index in the case of lower input rate (Fig. 4d) where it increased slightly compared to the two flumes with larger LW input rates, where it decreased to 1.3 and -0.9 , respectively. When vegetation colonizes the higher bars, the flumes showed a more consistent pattern, with the highest value of Sk for the first vegetated step (SVa and SVLWa in Fig. 4). Further vegetation growth and encroachment significantly reduced the skewness, particularly in flume 1, where it reached the minimum value at the end of the run. In the cases of the SVLW runs, after decreasing in the step b and c, the skewness increased again in the last survey. More negatively skewed distributions mean that vegetation colonization forces the main flow into a narrower and deeper channel, but in this case it is not equally effective in increasing bar height because of the lack of fine sediments.

\subsection{Second- order structure functions}

A two- dimensional second- order structure function (or semivariogram) of the bed surface elevations was used to quantify the correlation between elevations at various spatial scales. Semivariograms have been successfully used in fluvial geomorphology to analyse gravel-bed surfaces in previous studies (e.g., Marion et al., 2003; Aberle and Nikora, 2006; Cooper and Tait, 2009). The semivariograms of each run 
are plotted in terms of $\gamma / 2 \sigma^{2}$ versus the spatial lags in the stream-wise (Lx) and cross-stream (Ly) directions (Fig. 6, but see all of them in Figs. S1 and S2 in the supplementary material). The changes in slope of the semivariograms can be used to define different scaling regions dependent of the spatial lags, for instance the scale of grains (Nikora et al., 1998), sediment clusters (Strom and Papanicolaou, 2008), or bedforms (Clifford et al., 1992). High level of correlation between elevations corresponds to low values of $\gamma / 2 \sigma^{2}$, which is attained at small spatial scales.

At small spatial lags, the curves can be described with a power function between $\gamma / 2 \sigma^{2}$ and spatial lags (Nikora et al., 1998; Aberle and Nikora, 2006). At this small spatial scale, the scaling region is identified, and the exponent of the power function is called the scaling or Hurst exponent $(\mathrm{H})$. The Hurst exponent is generally considered a proxy for the complexity of bed elevations, with topographical complexity varying inversely with H (Bergeron, 1996).

The scaling exponent was rather small in the scans of flumes without vegetation (around 1), and much larger in the scans of vegetated channels flume (Fig. 7). When logs were added in vegetated channels flume, values were consistently high in both the cross-stream and stream-wise directions. Similarly, no marked differences are observed on the unvegetated channels flume with or without the presence of large wood. These results suggest that, despite the fact that vegetation increases the standard deviation of the elevations (e.g., higher depositional points and deeper pools), these elevations appear to be more regularly or evenly distributed on the surface, thus reducing the topographical complexity, as also suggested by the DEMs reported in Fig. 5. Also, higher $\mathrm{H}$ values tend to correspond to larger topographical patterns (Purkis and Kohler, 2008; Qin et al., 2019), which at this small spatial scale corresponds to features like pools that are larger and deeper in the SV and SVLW runs, as also suggested by the higher standard deviation of elevations.

As $\gamma / 2 \sigma^{2}$ approaches unity, the bed surface topography can be considered random in organization with respect to the reference point $\left(\mathrm{x}_{\mathrm{i}}, \mathrm{y}_{\mathrm{j}}\right)$ because the bed elevations have no correlation at that range of spatial lag. In all the scans analysed, the curves of the semivariogram on the stream-wise direction featured higher values than the cross-wise direction (Figs. 5 and S1). However, except for SV, the cross-wise correlation lengths $\left(\mathrm{L}_{\mathrm{y}}\right)$ featured comparable values to the stream-wise correlation lengths $\left(\mathrm{L}_{\mathrm{x}}\right)$ (Fig. 7). This suggests that the geometrical features that characterize the bed are rather elongated, such as bars. The correlation length for unvegetated and vegetated flumes is around 160-185 and 190-295 mm, respectively, which correspond approximately to the average width of single channels. The higher 
correlation length in flumes where vegetation and large wood act together could be in fact caused by

300 wider single channels if compared with unvegetated flumes.

301

302 4. Discussion

303

304

305

306

307

308

309

310

311

312

313

314

315

316

317

318

319

320

321

322

323

324

325

326

327

328

\subsection{The morphological role of large wood in braided rivers}

In these experiments neither the wood input rate nor wood storage volume are geomorphologically effective in changing the braiding index of the braided patterns of the flumes (Bertoldi et al., 2015). The flumes with input of large wood featured a similar average width of the anabranches, and a similar percentage of flume width occupied by active and dynamic channels. The present analysis of the PDFs confirms that even considering the 3D shape of the riverbed, the addition of $\mathrm{LW}$ to unvegetated channels does not modify significantly the braided morphology. This is the case in such a large flume with a selfformed braided pattern and uncongested input of wooden dowels much shorter than the river width. In narrower rivers, where the ratio between the length of the log pieces and channel width and the ratio between the piece diameter and the water depth are higher, logs tend to travel less, be trapped and capture other logs transported by the flow (Ruiz-Villanueva et al., 2016), creating large jams with considerable local morphological effects. In the current experiments, the lack of vegetation and the uncongested log transport, (typical of ordinary flood events) did not exert a noticeable morphological role on the selfformed braided topography. With the setup of the experiments, on the SL runs, the storage of logs in the channels increases with the wood input rate when the rate is high enough to allow for jams to form in channels (see Bertoldi et al., 2014).

The main results are summarized in a conceptual model reported in Fig. 8. In the S runs the vertical roughness is small, and mainly determined by features associated with wide and shallow multiple anabranches (Fig. 8). The skewness of the PDFs of elevations shows a longer tail towards lower elevations, revealing the presence of deeper pools rather than elevated features, likely because higher braiding involves a large number of pools. The semivariograms indicate that braided patterns are characterized by small correlation lengths and scaling exponents, suggesting that the main features (i.e., the anabranches and bars) tend to be narrow and with a high degree of complexity. Interestingly, once the physical presence of large wood is removed from the flumes (i.e., only the elevation of sandy features is considered), the topography of the flume with large wood (SLW) is fairly similar to a braided system without large wood (S-LW). This reveals that the main process responsible for the active and dynamic 
morphological changes of braided systems is associated with the fast migration of sediment bars

330 (Bertoldi, 2012). The presence of large wood is likely to change the location of channel avulsion, but the

331 entrainment and transport of large wood is not affected by the wood input rate (Bertoldi et al., 2014), and

332 the resulting channel morphology is not affected by the presence of large wood. Future experimental

333

334

335

336

337

338

339

340

341

342

343

344

345

346

347

348

349

350

351

352

353

354

355

356

357 attempts should explore the dynamics of avulsion processes led by wood accumulations in vegetated channels. A special emphasis should be devoted to experiments with different flood occurrence timing to allow large wood to be deposited in the floodplains in large accumulations as avulsions change the location of the main channel. It is likely the topographic characteristics of a system of this kind would result in a higher standard deviation of elevations.

\subsection{The morphological role of vegetation in braided rivers}

The morphological role of vegetation is well documented in the literature. Tal and Paola $(2007,2010)$ demonstrated in flume experiments that vegetation forces the flow in fewer and deeper channels. The experiments presented in this paper already showed that vegetation increases the stability of the banks, reducing the braiding index and transforming a braided into a wandering/single-thread morphology (Bertoldi et al., 2015). The present study adds to these observations, revealing a much wider distribution of bed surface elevations around the average, if compared with a braided morphology developed without the influence of vegetation (Fig. 8). Indeed, the standard deviation of elevations increases progressively as the vegetation encroaches on the bars, stabilizing them, and at the end of the experiments the standard deviation was two times higher than without vegetation. The progressive decrease of skewness of the PDFs reveals that channels are narrow and deeper than unvegetated channels (Fig. 8). As the vegetation progressively colonize the flume, the first pioneering islands diverge the flow and self-stabilize, increasing their height and favouring the scour of pools. Pioneer islands progressively become more reinforced by new seedlings, and the channels are less dynamic and much deeper. A higher scaling exponent for the experiments with vegetation growing in the flumes also suggests that the larger topographical patterns (deep pools and higher levees) are more evenly distributed in the flume. Longer experiments would have probably allowed large wood to be deposited in the floodplains in large accumulations as avulsions change the location of the main channel, resulting in a higher standard deviation of elevations and even a bimodal distribution of elevations. 

showed that vegetation encroaching on a sinuous sand-bedded channel in flume experiments caused the main channel to become deeper and the bars to increase in elevation because of sedimentation. Similarly, Lightbody et al. (2019) in a field-scale meandering flume facility showed that vegetation growing on bars created a deeper channel and the elevation of bar surfaces to increase because of sediment deposition.

363 Also, Jourdain et al. (2020) used a numerical model to show that the development of vegetation on bars led to a topographical evolution of a sinuous river. In their model, the channel becomes deeper and narrower, and the progressive deposition of sediments on the bars led to the creation of a bimodal distribution of elevations. This series of results obtained in flume experiments are also comparable with field observations. Consistent with our results, in a study of the braided Santa Maria River in Arizona, Bywater-Reyes et al. (2018) showed that the presence of vegetation was associated with higher standard deviation of elevations, and related this to larger volumes of sediment being deposited on vegetated patches of bars.

371 Similar observations are reported by Wintenberger et al. (2015) in the Loire River, where the progressive 372 development of vegetation on bars forced the topography to a wider distribution, with higher standard 373 deviation of elevations. In the Tagliamento River (Italy), Bertoldi et al. (2011) highlighted an increase of the skewness in more vegetated reaches, with values reaching 0, (i.e., a symmetrical bed elevation 375 frequency distribution). In our experiments the skewness actually decreased with vegetation, and this difference may be related to the absence of fine sediments in the experiments, thus limiting the effect of

377 vegetation on sediment deposition. The vegetated islands in the experiments were not likely to aggrade 378 because the transported sediments were deposited before reaching the top of the bars.

379 Despite the limits of simplifying natural river processes in a flume experiment, it seems quite relevant that the topographical nature of a river system forced by vegetation is consistently different in terms of the vertical distribution of elevations and synthetic indexes of semivariograms, if compared with what is

382 measured in a braided river without vegetation. Vegetation exerts a pervasive effect on earth surface 383 processes in a variety of contexts (Corenblit et al., 2011, 2019; Lee et al., 2019). Analysing the evolution of the fluvial landscapes over the past 250 million years, Gibling and Davies (2012) reported that before 385 vegetation covered Earth (Ordovician period), rivers were mainly large braided systems with unstable banks. Although the cohesiveness of sediments on the banks caused some rivers to meander even before the evolution of terrestrial plants (e.g., Lapôtre et al., 2019; Ganti et al., 2019; Pawlik et al., 2020), the 
growing and pervasive effect of vegetation on Earth likely shifted rivers to island braided and meandering patterns. Ielpi and Lapotre (2019) recently showed that the migration of meanders in alluvial rivers is reduced tenfold in vegetated environments. The analysis of the topographical signature of fluvial patterns in alluvial deposits could thus add to the interpretation of the evolution of rivers system evolved in the past as a response to major extinctions and climatic events (Gibling et al., 2015).

The biogeomorphological role of vegetation in determining processes and shaping surface properties can be potentially recognised in the imprint left by vegetation in landforms. This has been attempted in recognising the topographical signature of vegetation in rivers (Bertoldi et al., 2011), vegetation on dunes (Lee et al., 2019), and even on Mars (Corenblit et al., 2019). Our results show that the topography of gravel-bed rivers conditioned by vegetation is distinctly different than gravel-bed rivers not affected by vegetation. This could be potentially used to interpret the topography of braidplain alluvial deposits. In this sense, the morphological effect of large wood alone would more difficult to distinguish from the effect of vegetation, and one might argue that the presence of large wood would naturally be related with the presence of in-channel vegetation. However, large wood is also provided by the drainage basin, and large volumes of large wood can be recruited to the river network and transported during flood events (Comiti et al., 2016). It is interesting to mention here that a recent work by Gulbranson et al. (2020) on an ancient river system in Antarctica revealed that the transition from the Permian to the Triassic is characterized by rather different deposits. Interestingly, the authors identified the presence of large wood deposits in the braided deposits. In the Permian the river was braided with sparse vegetation and wood jams, whereas in the Triassic wood jams appear to occur without evidence of vegetated in-channel macroforms.

Despite the potential of interpreting contemporary or ancient topographies of braided patterns in order to infer the relative importance of vegetation or large wood in the topographical development of river systems, it is also worth stressing the challenges associated with establishing a unequivocal relationship between a series of topographical or morphological features and the independent variables and boundary conditions that created them. Nanson and Huang (2018) suggest that rivers subject to different environmental controls can evolve to convergent similar shapes. Indeed, as showed by Stecca et al. (2019), similar converging morphological trajectories can be recognised in rivers dominated by different processes, and this could apply to the topographical signature of gravel-bed rivers affected by vegetation or fine cohesive sediments. 
420 To our knowledge, this set of experiments are so far the only attempt to simulate the geomorphic effects of vegetation and large wood separately as well as together in braided gravel-bed rivers. Disentangling

422 the role of vegetation and large wood is very challenging in natural rivers as these factors act together,

423 and their relative topographical effects on braided rivers have never been explored before. These

424

425

426

427

428

429

430

431

432

433

434

435 experiments revealed that with the combined action of large wood and vegetation, the braiding index of a river systems is reduced even further, forcing the braided channel into a wandering or single-thread planform (Bertoldi et al. 2015). Similar to the results of Gran and Paola (2001), in our experiments large wood accumulations reinforced the stabilizing effects of vegetation even more, reducing the lateral mobility of the anabranch. From a planimetric point of view, the average width of the channels was only slightly wider if compared with the runs with only vegetation, even if there was a slight reduction of the braiding index. However, the combined action of vegetation and large wood had a larger effect on the topographical nature of the PDFs. Large wood tended to divert the flow towards the bank, increasing localized bank erosion and the average channel width, and this corresponds to a reduced standard deviation of the bed elevation. However, skewness of the bed elevations increases probably because of the presence of shallower scours than SV channels (Fig. 8).

The reduction of the braiding index in the runs with the combined effects of large wood and vegetation was unexpected. Indeed, field evidence suggests that, if pioneer islands survive long enough, they are able to trap more sediment and propagules, forming large islands on gravel bar surfaces (Gurnell et al., 2005). This process maintains a dynamic island-braided morphology (Bertoldi et al., 2011). Cadol and Wohl (2011) also reported that key large wood elements were responsible for maintaining the multithread pattern of island-braided channels in several reaches of the North St. Vrain Creek in the Rocky Mountain National Park (Colorado). In the conceptual model developed by Collins et al. (2011), pieces of wood large enough to resist fluvial transport can initiate and stabilize wood accumulations, which in turn create alluvial patches and protect them from erosion, contributing to change the topography of the floodplain and increase the number of channels. Floodplains indeed store great quantities of wood deposited by floods (Wohl et al., 2018).

The length of our experiments was probably too short to allow the occurrence of several avulsions of the main channel and the accumulation of large volumes of large wood in the floodplain. Indeed, the presence 
of two large wood jams in $\mathrm{C} 3$ created a mid-bar that split the flow, maintaining a constant braiding index

449 until the end of the experiments. A longer experiment would have probably lead to a complete avulsion of 450 the system, which would have created higher braiding-index and dynamicity in the system, as large wood accumulations are reported to increase the chances of avulsions (e.g., Abbe and Montgomery, 2003;

452 Webb and Erskine, 2003).

453

\section{5. Conclusions}

455 Flume experiments were carried out to explore the role of large wood and vegetation on determining the 456 topography of braided river systems. Results show that vegetation growing on the bars of the flume 457 channels reduced the braiding index and the space available for the flowing water resulting in fewer, 458 wider and deeper channels. Deeper channels and localized sediment accumulations result in a higher 459 standard deviation of the bed elevations. Large wood alone is not effective in determining the topography 460 of the braided pattern if compared with the morphological effects of vegetation. Indeed, large wood causes only a slight reduction of both the mean channel width and braiding index. Also, the standard

462 deviation of bed surface elevations is comparable with the value measured for the experiments conducted 463 with sand alone. Interesting, when large wood is introduced in the flumes where vegetation is growing, this is not effective in changing the average channel width, or the braiding index, but the bed surface becomes relatively smoother (e.g., with less deep scours) if compared with the bed on flumes with only vegetation, resulting in an increase of the skewness towards positive values. The structure functions allowed us to compare the flume channels in terms of the extent of their scaling region and correlation lengths. This set of evidence shows that vegetation and large wood can modify the channel morphology but also lead to significant changes in the topographical nature of the braidplain, which can be interpreted by the analysis of digital elevation models. The implications are relevant in terms of river restoration, as the artificial placement of large wood in braided rivers with islands could lead to the reduction of the

472 braiding index and average channel width. Potential implications refer also to the interpretation of 473 deposits of ancient river systems.

\section{Acknowledgments}

476 The work described in this publication was supported by the European Community's Seventh Framework Programme through the grant to the budget of the Integrating Activity HYDRALAB IV, Contract no. 
helped in the executions of the experiments. Stephanie Orellana who helped in the elaboration of the data.

Francesco Comiti, Angela Gurnell and Michal Tal greatly helped in the experimental design. We thank

Lucy Clarke and two anonymous reviewers for providing several constructive commentaries on a first

version of the manuscript.

485

486

487

488

489

490

491

492

493

494

495

496

497

498

499

500

501

502

503

504

505

506

507

508

509

510

511

512

513

514

515

516

517

518

519

520

521

522

523

524

525

526

527

528

529

\section{References}

Abbe T.B., Montgomery D.R., 2003. Patterns and processes of wood debris accumulation in the Queets river basin, Washington. Geomorphology 51, 81-107.

Abbe T.B. and Montgomery D.R., 1996. Large woody debris jams, channel hydraulics and habitat formation in large rivers. Regulated Rivers Research and Management 12, 201-221.

Abbe T.B., Brooks A.P., Montgomery D.R., 2003. Wood in river rehabilitation and management. In The Ecology and Management of Wood in World Rivers, Gregory SV, Boyer KL, Gurnell AM (eds). American Fisheries Society: Bethesda, MD, 367-389.

Aberle J., Nikora V., 2006. Statistical properties of armored gravel bed surfaces. Water Resour. Res., 42, W11414.

Bergeron N.E., 1996. Scale-space analysis of stream-bed roughness in coarse gravelbed streams. Math. Geol. 28, 537-561.

Bertoldi W., Gurnell A.M., Drake N.A., 2011. The topographic signature of vegetation development along a braided river: results of a combined analysis of airborne lidar, color air photographs, and ground measurements. Water Resources Research 47,1-13. DOI:10.1029/ 2010wr010319.W06525

Bertoldi W., Gurnell A.M., Welber M., 2013. Wood recruitment and retention: the fate of eroded trees on a braided river explored using a combination of field and remotely-sensed data sources. Geomorphology 180-181, 146-155.

Bertoldi W., Ruiz-Villanueva V., 2017. Physical and Numerical Modelling of Large Wood and Vegetation in Rivers. GBR8.

Bertoldi W., Welber M., Gurnell A.M., Mao L., Comiti F., Tal M., 2015. Physical modelling of the combined effect of vegetation and wood on river morphology. Geomorphology 246, 178-187.

Bertoldi W., 2012. Life of a bifurcation in a gravel-bed braided river. Earth Surface Processes and Landforms 37(12), 1327-1336.

Bertoldi W., Siviglia A., Tettamanti S., Toffolon M., Vetsch, D., Francalanci, S., 2014. Modeling vegetation controls on fluvial morphological trajectories. Geophys. Res. Lett. 41, 7167-7175. DOI:10.1002/2014GL061666

Bocchiola D., Rulli M.C., Rosso R., 2006. Flume experiments on wood entrainment in rivers. Advances in Water Resources 29, 1182-1195.

Braudrick C.A., Dietrich W.E., Leverich G.T., Sklar L.S., 2009. Experimental evidence for the conditions necessary to sustain meandering in coarse-bedded rivers. Proceedings of the National Academy ofScience USA 106, 16936-16941.

Braudrick C.A., Grant G.E., Ishikawa Y., Ikeda H., 1997. Dynamics of wood transport in streams: a flume experiment. Earth Surface Processes and Landforms 22, 669-683.

Braudrick C.A., Grant G.E., 2000. When do logs move in rivers? Water Resources Research 36, 571-583.

Brooks A.P., Brierley G.J., Millar R.G., 2003. The long-term control of vegetation and woody debris on channel and floodplain evolution: insights from a paired catchment study in southeastern Australia. Geomorphology 51, 7-29.

Brown T.A., 2006. Confirmatory factor analysis for applied research. New York: Guilford Press.

Brummer C.J., Abbe T.B., Sampson J.R., Montgomery D.R., 2006. Influence of vertical channel change associated with wood accumulations on delineating channel migration zones, Washington, USA, Geomorphology 80(3), 295-309. DOI:10.1016/j.geomorph.2006.03.002

Buffington J.M., Montgomery D.R., 1999. Effects of hydraulic roughness on surface textures of gravelbed rivers. Water Resources Research 35, 3507-3521. 
Bywater-Reyes S., Wilcox A.C., Diehl R.M., 2017. Multiscale influence of woody riparian vegetation on fluvial topography quantified with ground-based and airborne lidar. Journal of Geophysical Research: Earth Surface 122, 1218-1235.

Cadol D., Wohl E., 2011. Coarse sediment movement in the vicinity of a logjam in a neotropical gravelbed stream. Geomorphology 128(3-4), 191-198.

Clarke L., 2014. The use of live vegetation in geomorphological experiments: how to create optimal growing conditions. Earth Surface Processes and Landforms 39, 705-710.

Collins B.D., Montgomery D.R, Fetherston K.L, Abbe T.B., 2011. The floodplain large-wood cycle hypothesis: A mechanism for the physical and biotic structuring of temperate forested alluvial valleys in the north pacific coastal ecoregion. Geomorphology 139-140, 460-470.

Collins B.D., Montgomery D.R., Fetherston K.L., Abbe T.B., 2012. The floodplain large wood cycle hypothesis: a mechanism for the physical and biotic structuring of temperate forested alluvial valleys in the North Pacific coastal ecoregion. Geomorphology 139, 460-470.

Collins B.D., Montgomery D.R., Haas A.D., 2002. Historical changes in the distribution and functions of large wood in Puget Lowland rivers. Can. J. Fish. Aquat. Sci. 59(1), 66-76. DOI:10.1139/f01-199.

Collins D.B.G.,Comiti F, Lucía A, Rickenmann D. 2016. Large wood recruitment and transport during large floods: a review. Geomorphology 269, 23-39.

Bras R.L., Tucker G.E., 2004. Modeling the effects of vegetation-erosion coupling on landscape evolution. J. Geophys. Res. 109, F03004. DOI:10.1029/2003JF000028

Cooper J.R., Tait S.J., 2009. Water- worked gravel beds in laboratory flumes-A natural analogue?, Earth Surf. Processes Landforms 34, 384-397. DOI:10.1002/esp.1743.

Corenblit D., Baas A.C., Bornette G., Darrozes J., Delmotte S., Francis R.A., Gurnell A.M., Julien F., Naiman R.J., Steiger J., 2011. Feedbacks between geomorphology and biota controlling earth surface processes and landforms: A review of foundation concepts and current understandings. Earth-Science Reviews 106(3-4), 307-331.

Corenblit D., Darrozes J., Julien F., Otto T., Roussel E., Steiger J., Viles H., 2019. The search for a signature of life on Mars: A biogeomorphological approach. Astrobiology 19, 1279-1291.

Corenblit D., Steiger J., 2009. Vegetation as a major conductor of geomorphic changes on the earth surface: toward evolutionary geomorphology. Earth Surface Processes and Landforms 34, 891-896.

Cotton C.A., 1955. New Zealand Geomorphology, 281 pp., N. Z. Univ. Press, Wellington.

Dietrich WE, Perron JT. 2006. The search for a topographic signature of life. Nature 439, 411-418. DOI:10.1038/nature04452.

Eaton B.C., Giles T.R., 2009. Assessing the effect of vegetation-related bank strength on channel morphology and stability in gravel-bed streams using numerical models. Earth Surf. Process. Landf. 34, 712-724. DOI:10.1002/esp.1768.

Egozi R., Ashmore P.E., 2008. Defining and measuring braiding intensity. Earth Surface Processes and Landforms 33(14), 2121-2138.

Fernández R.L., Dijkstra J., Thom M., McLelland S., 2019. Protocols for scaling 529 biogeomorphology in time. Hydralab+ Deliverable 8.V.

Francis R.A., Petts G.E., Gurnell A.M., 2008. Wood as a driver of past landscape change along river corridors. Earth Surf. Process. Landforms 33, 1622-1626.

Ganti V., Whittaker A.C., Lamb M.P., Fischer W.W., 2019. Low-gradient, single-threaded rivers prior to greening of the continents. PNAS, 116(24), 11652-11657.

Ganti V., Whittaker A.C., Lamb M.P, Fischer W.W., 2019. Low-gradient, single-threaded rivers prior to greening of the continents. Proceedings of the National Academy of Sciences, 116 (24), 1165211657.

Gibling M.R., Davies N.S., 2012. Palaeozoic landscapes shaped by plant evolution. Nat. Geosci. 5, 99105.

Goring D.G., Nikora V.I., McEwan I.K., 1999. Analysis of the texture of gravel-beds using 2-D structure functions. Proceedings of the I.A.H.R. Symposium on River, Coastal and Estuarine Morphodynamics, Genova, Italy, 111-120.

Gran K., Paola C., 2001. Riparian vegetation controls on braided stream dynamics. Water Resources Research 37, 3275-3283.

Griffin M.M., Steinbrecher T.D., 2013. Large-scale datasets in special education research. International Review of Research in Developmental Disabilities 45, 155-183. DOI:10.1016/B978-0-12-4077607.00004-9.

Gulbranson GL, Cornamusini G, Ryberg PE, Corti V. 2020. When does large woody debris influence ancient rivers? Dendrochronology applications in the Permian and Triassic, Antarctica. Palaeogeography, Palaeoclimatology, Palaeoecology, 541, 109544.Gurnell A.M., Bertoldi W., 
Corenblit D., 2012. Changing river channels: the roles of hydrological processes, plants and pioneer fluvial landforms in humid temperate, mixed load, gravel bed rivers. Earth Sci. Rev. 111, 129-141.

Gurnell A.M., England J., Burgess- Gamble L., 2018. Trees and wood: working with natural river processes. Water and Environment Journal. DOI:10.1111/wej.12426.

Gurnell A.M., Petts G.E., 2006. Trees as riparian engineers: the Tagliamento River, Italy. Earth Surface Processes and Landforms 31(12), 1558-1574.

Gurnell A.M., Tockner K., Edwards P.J., Petts G.E., 2005. Effects of deposited wood on biocomplexity of river corridors. Front. Ecol. Environ. 3 (7), 377-382.

Harvey G.L., Henshaw A.J., Parker C., Sayer C.D., 2018. Re- introduction of structurally complex wood jams promotes channel and habitat recovery from over widening: Implications for river conservation. Aquatic Conserv: Mar. Freshw. Ecosyst. 28, 395-407. DOI:10.1002/aqc.2824.

Hyatt T.L., Naiman R.J., 2001. The residence time of large woody debris in the Queets River, Washington. Ecological Applications 11,191-202.

Ielpi A., Lapôtre M.G.A., 2020. A tenfold slowdown in river meander migration driven by plant life. Nat. Geosci. 13, 82-86.

Istanbulluoglu E., Bras R.L., 2005. Vegetation-modulated landscape evolution: Effects of vegetation on landscape processes, drainage density, and topography, J. Geophys. Res. 110, F02012. DOI:10.1029/ 2004JF000249.

Jeffries R., Darby S.E., Sear D.A., 2003. The influence of vegetation and organic debris on floodplain sediment dynamics: Case study of a low-order stream in the New Forest, England, Geomorphology 51(1-3), 61-80. DOI:10.1016/S0169-555X(02)00325-2.

Jourdain C., Claude N., Tassi P., Cordier F., Antoine G., 2020. Morphodynamics of alternate bars in the presence of riparian vegetation. Earth Surf. Process. Landforms 45, 1100-1122.

Keller E.A., Swanson F.J., 1979. Effects of large organic material on channel form and fluvial processes. Earth Surface Processes and Landforms 4(4), 361-380.

Kline R.B., 2005. Principle and practice of structural equation modeling. New York: Guilford.

Lapôtre M.G.A., Ielpi A., Lamb M.P., Williams R.M.E., Knoll A.H., 2019. Model for the formation of single- thread rivers in barren landscapes and implications for pre- Silurian and Martian fluvial deposits. Journal of Geophysical Research: Earth Surface, 124. DOI:10.1029/2019JF005156.

Lee D.B., Ferdowsi B., Jerolmack D.J., 2019. The imprint of vegetation on desert dune dynamics. Geophysical Research Letters 46. DOI:10.1029/2019GL084177.

Lehner B., Liermann C.R., Revenga C., Vörösmarty C., Fekete B., Crouzet P., Döll P., Endejan M., Frenken K., Magome J., Nilsson C., Robertson J.C., Rodel R., Sindorf N., Wisser D., 2011 Highresolution mapping of the world's reservoirs and dams for sustainable river-flow management. Front Ecol Environ 9, 494-502. DOI:10.1890/100125.

Lightbody A.F., Kui L., Stella J.C., Skorko K.W., Bywater-Reyes S., Wilcox A.C., 2019. Riparian Vegetation and Sediment Supply Regulate the Morphodynamic Response of an Experimental Stream to Floods. Frontiers in Environmental Science, 40. DOI:10.3389/fenvs.2019.

Mao L., Cooper J.R., Frostick L.E., 2011. Grain size and topographical differences between static and mobile armour layers. Earth Surface Processes and Landforms 36(10), 1321-1334.

Marion A., Tait S.J., McEwan I.K., 2003. Analysis of small- scale gravel bed topography during armouring. Water Resources Research 39(12), 1334. DOI:10.1029/2003WR002367.

Millar R.M., 2000. Influence of bank vegetation on alluvial channel patterns. Water Resources Research 36(4), 1109-1118.

Monin A.S., Yaglom A.M., 1975. Statistical Fluid Mechanics, vol. 2, MIT Press, Cambridge, Mass.

Montgomery D.R., Abbe T.B., 2006. Influence of logjam-formed hard points on the formation of valleybottom landforms in an old-growth forest valley, Queets River, Washington, USA. Quaternary Research 65, 147-155.

Moretto J., 2014. Linking river channel forms and processes in gravel bed rivers: time, space, remote sensing and uncertainly. PhD Thesis. University of Padova, Italy.

Murray A.B., Paola C., 2003. Modelling the effect of vegetation on channel pattern in bedload rivers. Earth Surf. Process. Landf. 28, 131-143. DOI:10.1002/ esp.428.

Nikora V.I., Goring D.G., Biggs B.J.F., 1998. On gravel-bed roughness characterization. Water Resources Research 34, 517-527.

O'Connor J.E., Jones M.A., Haluska T.L., 2003. Flood plain and channel dynamics of the Quinault and Queets Rivers, Washington, USA. Geomorphology 51, 31-59.

Paola C., Straub K., Mohrig D., Reinhardt L., 2009. The "unreasonable effectiveness" of stratigraphic and geomorphic experiments. Earth Science Reviews 97, 1-43. 
Pawlik L., Buma B., Šamonil P., Kvaček J., Gałązka A., Kohout P., Malik I., 2020. Impact of trees and forests on the Devonian landscape and weathering processes with implications to the global Earth's system properties - A critical review. Earth-Science Reviews 205, 103200.

Pfeiffer A.M., Finnegan N.J., Willenbring J.K., 2017. Sediment supply controls equilibrium channel geometry in gravel rivers, Proc. Natl. Acad. Sci., 201612907. DOI:10.1073/pnas.1612907114.

Piégay H., Gurnell A.M., 1997. Large woody debris and river geomorphological pattern: examples from S. E. France and S. England. Geomorphology 19, 99-116.

Qin J., Aberle J., Henry P., Wu T., Zhong D., 2019. Statistical significance of spatial correlation patterns in armoured gravel beds. Journal of Hydraulic Research, 57(1), 90-106.

Rice S., Church M., 1996. Sampling surficial fluvial gravels: The precision of size distribution percentile estimates. J. Sediment. Res. 66(3), 654-665.

Robert A., Richards K.S., 1988. On the modelling of sand bedforms using the semivariogram. Earth Surf. Proc. Land. 13(5), 459-473.

Robert A., 1988. Statistical properties of sediment bed profiles in alluvial channels. Mathematical Geology 20, 205-225.

Ruiz-Villanueva V., Mazzorana B., Bladé E., Bürkli L., Iribarren-Anacona P., Mao L., Nakamura F., Ravazzolo D., Rickenmann D., Sanz-Ramos M., Stoffel M., Wohl E., 2019. Characterization of wood-laden flows in rivers. Earth Surf. Process. Landf. 44, 1694-1709.

Sedell J.R., Froggatt J.L., 1984. Importance of streamside forests to large rivers: the isolation of the Willamette River, Oregon, U.S.A., from its floodplain by snagging and streamside forest removal. Verhandlungen der Internationalen Vereinigung fur theoretische und angewandte Limnologie 22, $1828-1834$.

Simon A., Collison A.J.C., 2002. Quantifying the mechanical and hydrologic effects of riparian vegetation on streambank stability. Earth Surface Processes and Landforms 27, 527-546.

Stecca G., Zolezzi G., Hicks M., Surian N., 2019. Reduced braiding of rivers in human-modified landscapes: Converging trajectories and diversity of causes. Earth-Science Reviews 188, 291-311.

Tal M., Paola C., 2007. Dynamic single-thread channels maintained by the interaction of flow and vegetation. Geology 35(4), 347-350.

Tal M., Paola C., 2010. Effects of vegetation on channel morphodynamics: results and insights from laboratory experiments. Earth Surface Processes and Landforms 35(9), 1014-1028.

Van Dijk W.M., Teske R., Van de Lageweg W.I., Kleinhans M.G., 2013. Effects of Vegetation Distribution on Experimental River Channel Dynamics. Water Resources Research 49 (11), 7558 7574. DOI:10.1002/2013WR013574.

Vargas- Luna A., Duró G., Crosato A., Uijttewaal W., 2019. Morphological adaptation of river channels to vegetation establishment: A laboratory study. Journal of Geophysical Research: Earth Surface 124. DOI:10.1029/2018JF004878.

Wallerstein N.P., Alonso C.V., Bennett S.J., Thorne C.R., 2001. Froude-scaled flume analysis of large woody debris. Earth Surface Processes and Landforms 26(12), 1265-1283.

Waters K.A., Curran J.C., 2015. Linking bed morphology changes of two sediment mixtures to sediment transport predictions in unsteady flows. Water Resour. Res. 51(4), 2724-2741.

Welber M., Bertoldi W., Tubino M., 2013. Wood dispersal in braided streams: results from physical modeling. Water Resources Research 49, 7388-7400.

Wintenberger C.L., Rodrigues S., Bréhéret J.G., Villar M., 2015. Fluvial islands: First stage of development from nonmigrating (forced) bars and woody-vegetation interactions. Geomorphology 246, 305-320. DOI:10.1016/j.geomorph.2015.06.026.

Wohl E., Cadol D., 2011. Neighbourhood matters: patterns and controls on wood distribution in oldgrowth forest streams of the Colorado Front Range, USA. Geomorphology 125, 132-146.

Wren D.G., Langendoen E.J., Kuhnle R.A., 2014. A note on acoustic measurements of turbulence, suspended sediment, and bed forms in mobile-bed experiments. J. Hydro-environ. Res. 8, 164-173. 
Table 1. Details of the conditions during the experiments in the flumes. Experiments were conducted on three parallel channels (named C1, C2, and C3) with only sand (S), sand and large wood (SLW), sand and vegetation (SV), and sand, vegetation, and large wood together (SVLW). Additional measurements were taken after the SLW runs, after the large wood pieces were removed from the sand bed (S-LW). Laser scan surveys were carried out at the end of each run on each flume channel. The discharge used for the steady flow and pulses was $1.261 \cdot \mathrm{s}^{-1}$, and the sand feeding rate as $1.9 \mathrm{~g} \cdot \mathrm{s}^{-1}$.

\begin{tabular}{|c|c|c|c|}
\hline RUN & C1 & C2 & C3 \\
\hline $\mathbf{S}$ (only sand bed) & $\begin{array}{l}\text { Steady flow and sand } \\
\text { feeding }\end{array}$ & $\begin{array}{l}\text { Steady flow and sand } \\
\text { feeding }\end{array}$ & $\begin{array}{l}\text { Steady flow and sand } \\
\text { feeding }\end{array}$ \\
\hline $\begin{array}{l}\text { SLW (sand and large } \\
\text { wood) }\end{array}$ & $\begin{array}{l}\text { Steady flow, sand } \\
\text { feeding and logs } \\
\text { feeding }\left(40 \operatorname{logs} \cdot \mathrm{h}^{-1}\right)\end{array}$ & $\begin{array}{l}\text { Steady flow, sand } \\
\text { feeding and logs } \\
\text { feeding }\left(80 \operatorname{logs} \cdot \mathrm{h}^{-1}\right)\end{array}$ & $\begin{array}{l}\text { Steady flow, sand } \\
\text { feeding and logs } \\
\text { feeding }\left(120 \operatorname{logs} \cdot \mathrm{h}^{-1}\right)\end{array}$ \\
\hline $\begin{array}{l}\text { S-LW (sand minus } \\
\text { large wood) }\end{array}$ & $\begin{array}{l}\text { Logs were manually } \\
\text { and carefully removed } \\
\text { from the channel } \\
\text { without moving sand }\end{array}$ & $\begin{array}{l}\text { Logs were manually } \\
\text { and carefully removed } \\
\text { from the channel } \\
\text { without moving sand }\end{array}$ & $\begin{array}{l}\text { Logs were manually } \\
\text { and carefully removed } \\
\text { from the channel } \\
\text { without moving sand }\end{array}$ \\
\hline $\begin{array}{l}\text { SV (sand and } \\
\text { vegetation) } \\
\text { SVa at } 1 / 4 \text { of the run } \\
\mathrm{SVb} \text { at } 1 / 2 \text { of the run } \\
\mathrm{SVc} \text { at } 3 / 4 \text { of the run } \\
\mathrm{SVd} \text { at the end of the } \\
\text { run }\end{array}$ & $\begin{array}{l}\text { Vegetation growing } \\
\text { and re-seed every } 7 \\
\text { days; } \\
\text { Steady base-flow with } \\
\text { four high-flow pulses } \\
\text { every } 7 \text { days }\end{array}$ & & \\
\hline $\begin{array}{l}\text { SVLW (sand, } \\
\text { vegetation and large } \\
\text { wood) } \\
\text { SVLWa at } 1 / 4 \text { of the run } \\
\text { SVLWb at } 1 / 2 \text { of the run } \\
\text { SVLWc at } 3 / 4 \text { of the run } \\
\text { SVLWd at the end of } \\
\text { the run }\end{array}$ & & $\begin{array}{l}\text { Vegetation growing } \\
\text { and re-seed every } 7 \\
\text { days; } \\
\text { Steady base-flow with } \\
\text { four high-flow pulses } \\
\text { every } 7 \text { days, and logs } \\
\text { feeding }\left(40 \operatorname{logs} \cdot h^{-1}\right)\end{array}$ & $\begin{array}{l}\text { Vegetation growing } \\
\text { and re-seed every } 7 \\
\text { days; } \\
\text { Steady base-flow with } \\
\text { four high-flow pulses } \\
\text { every } 7 \text { days, and logs } \\
\text { feeding }\left(120 \operatorname{logs} \cdot \mathrm{h}^{-1}\right)\end{array}$ \\
\hline
\end{tabular}


Figure 1. Stitched images of the four experimental scenarios. A: runs with only sand (S); B: runs with sand and large wood (SLW); C: runs with sand and vegetation (SV); and D: runs with sand, vegetation and large wood (SVLW). The images refer to channels at the end of the runs of each scenario. The flow direction is from left to right, and the water is coloured red by an organic ink.

Figure 2. Braiding index $(\mathrm{Bi})$, relative channel width, and the average width of active channels of the flumes created on experiments without vegetation (S and SLW) and with vegetation (SV and SVLW) encroaching in the channel flumes. The whiskers represent the $10^{\text {th }}$ and $90^{\text {th }}$ percentiles, the box limits indicate the $25^{\text {th }}$ and $75^{\text {th }}$ percentiles and the square icon within the box marks the median.

Figure 3. The probability density function of the bed elevations at the end of each run of the experiment in channel 1 (A), channel 2 (B), and channel 3 (C).

Figure 4. Standard deviation $(\delta)$ and skewness (Sk) of the bed elevation for each experimental run on channels 1 ( $\mathrm{A}$ and $\mathrm{D}), 2$ (B and $\mathrm{E})$ and 3 (C and $\mathrm{F}$ ).

Figure 5. Detrended and filtered DEMs for C2 and runs S, SLW, SVLWa, SVLWb, SVLWc, SVLWd (see Table 1 for details). Lowest $5 \%, 10 \%, 15 \%$ points are highlighted in magenta, red and pink, respectively. Flow is from bottom to top.

Figure 6. Example of second-order structure functions of the bed surface elevations of the SVLWc scan. Black and grey lines refer to structure functions calculated in the stream- wise and cross- stream directions, respectively.

Figure 7. The correlation length $1(\mathrm{~A}$ and $\mathrm{B})$ and the scaling exponent $\mathrm{H}(\mathrm{C}$ and $\mathrm{D})$ derived for the streamwise $\left(\mathrm{H}_{\mathrm{x}}\right.$ and $\left.\mathrm{l}_{\mathrm{x}}\right)$ and the cross-stream $\left(\mathrm{H}_{\mathrm{y}}\right.$ and $\left.\mathrm{l}_{\mathrm{y}}\right)$ directions on the different scenarios.

Figure 81. Conceptual model of the effects of vegetation and large wood on the topography of a generic braided river. Braiding index (Bi), percentage of flume width occupied by active channels (W\%), average channel width $(\bar{W})$, standard deviation $(\delta)$, skewness (Sk), correlation length $(\mathrm{L})$ and scaling exponent $(\mathrm{H})$ of multithread rivers due to the action of sand (S), large wood (SLW), vegetation (SV), and vegetation and large wood acting together (SVLW).

Figure 1S. Second-order structure functions of the bed surface elevations for the scans available of all experimental runs. Black and grey lines refer to structure functions calculated in the stream- wise and cross- stream directions, respectively.

Figure 2S. Isopleths maps of the second-order structure functions of the bed surface elevations for the scans available for all experimental runs. 


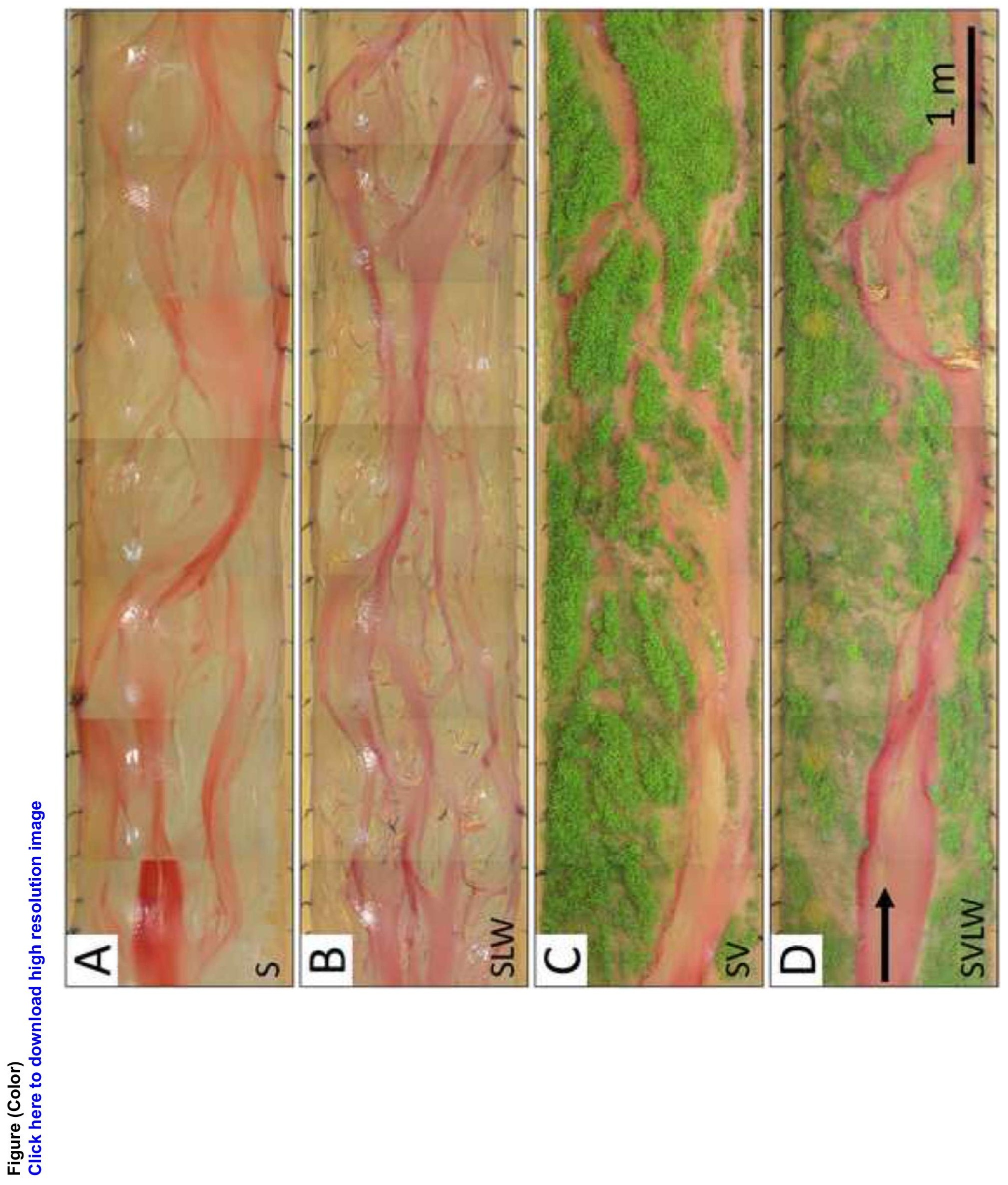




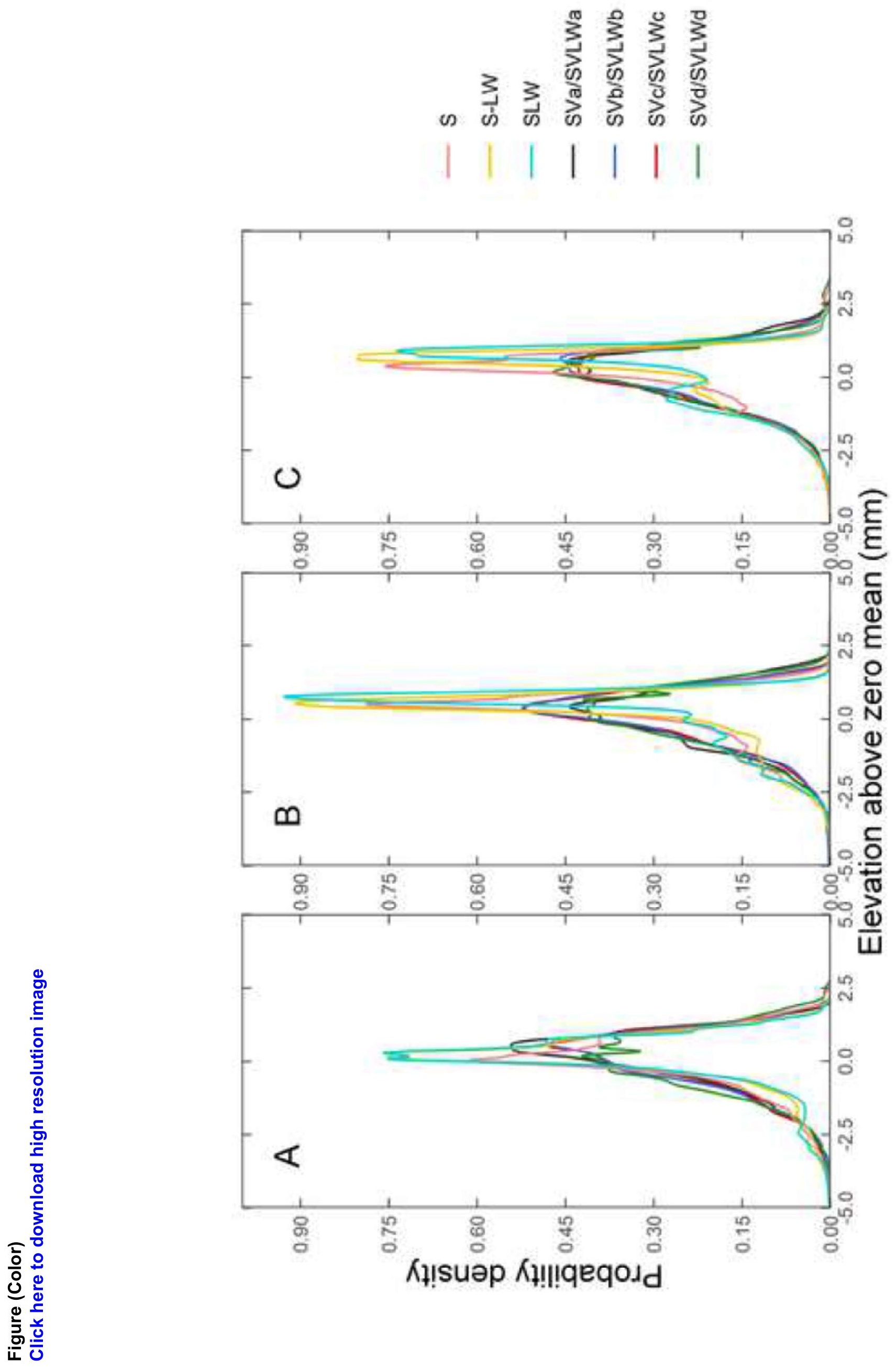



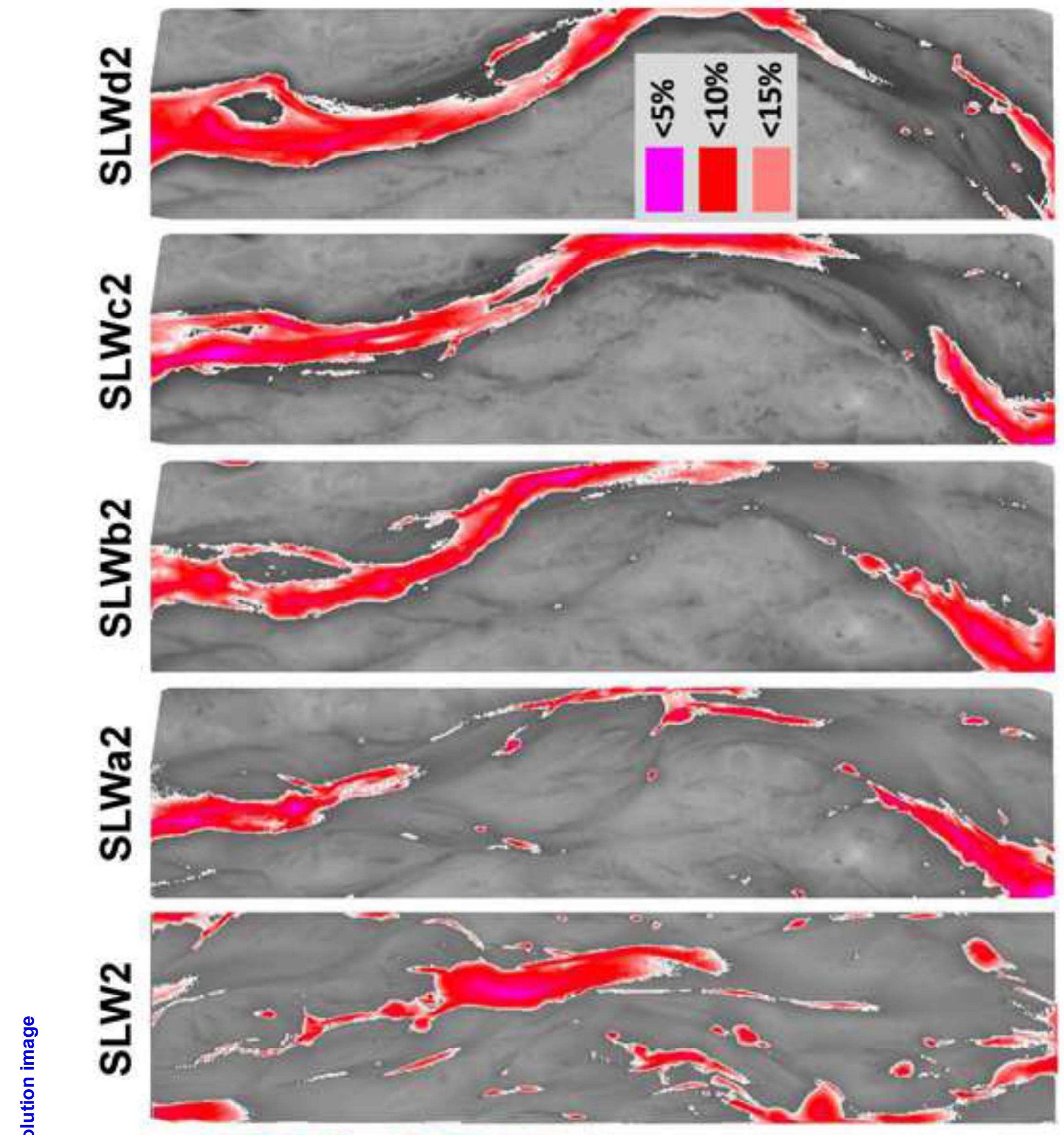

흥

응

U

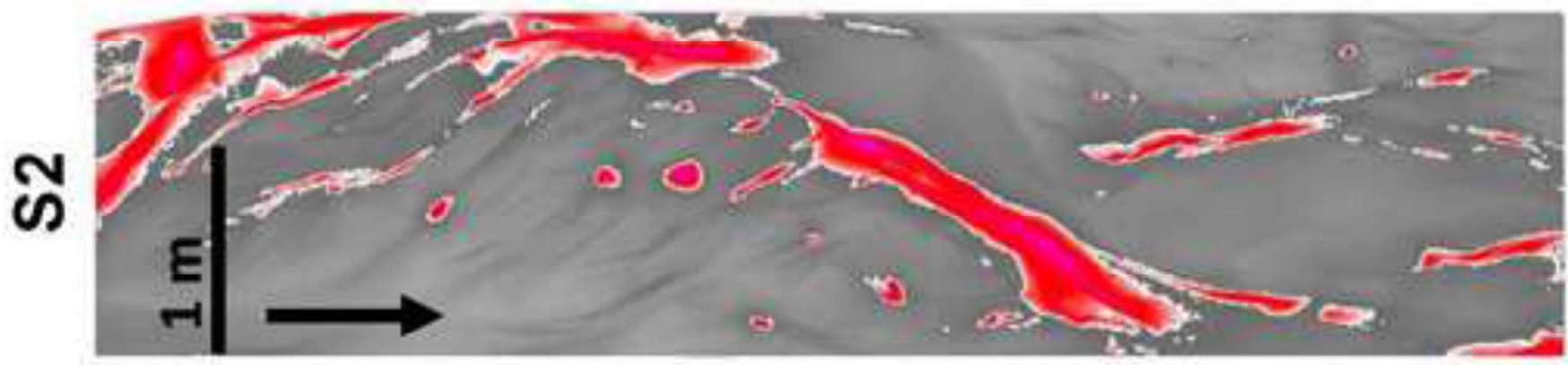



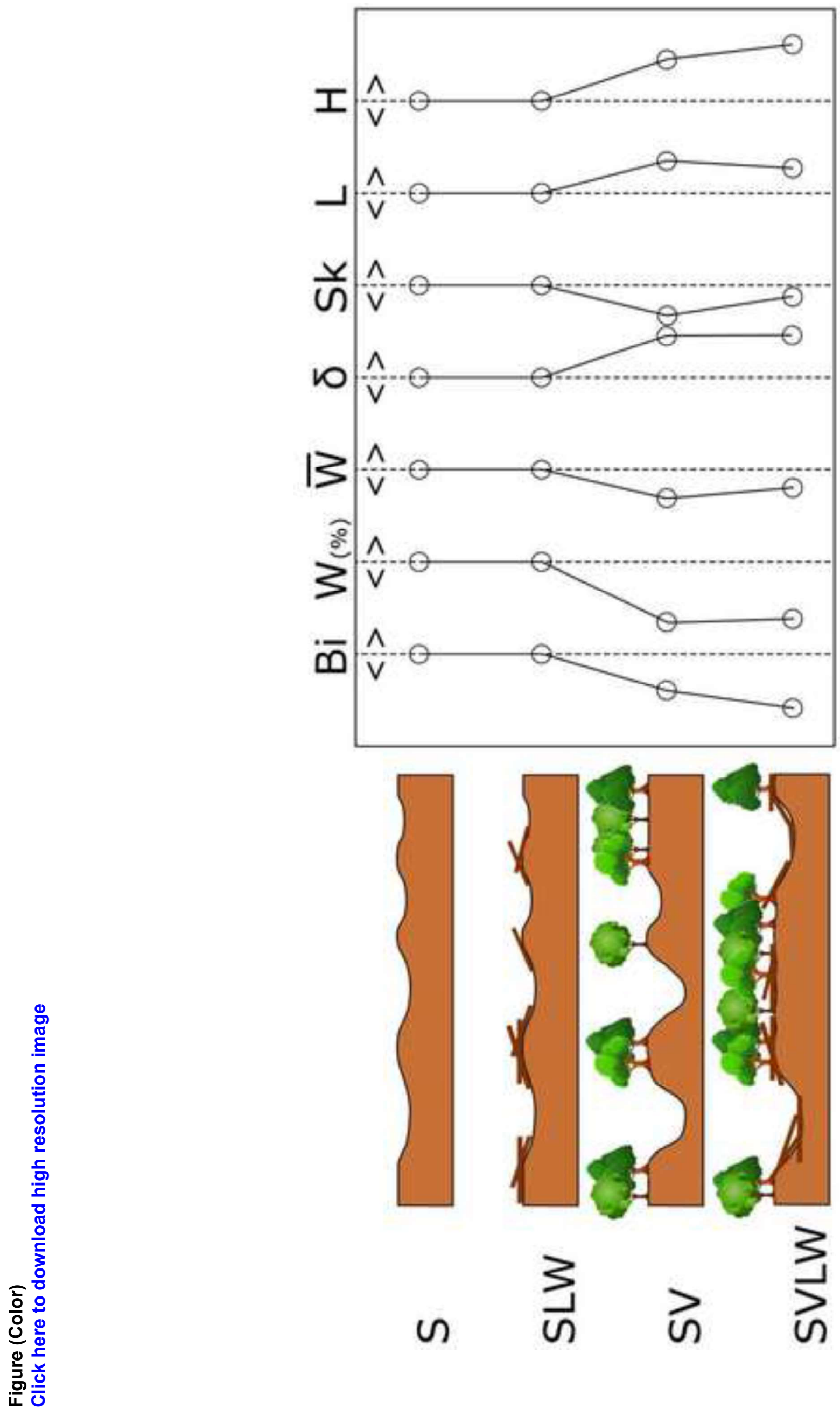


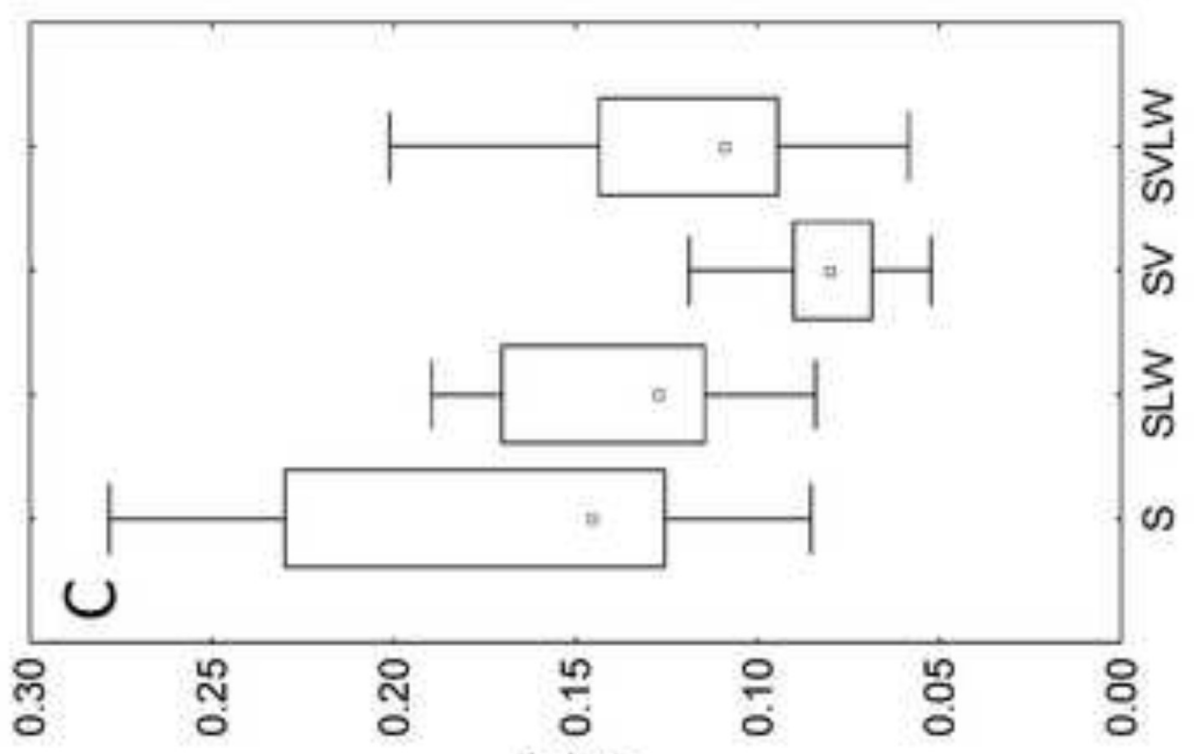

(i) $\underline{M}$

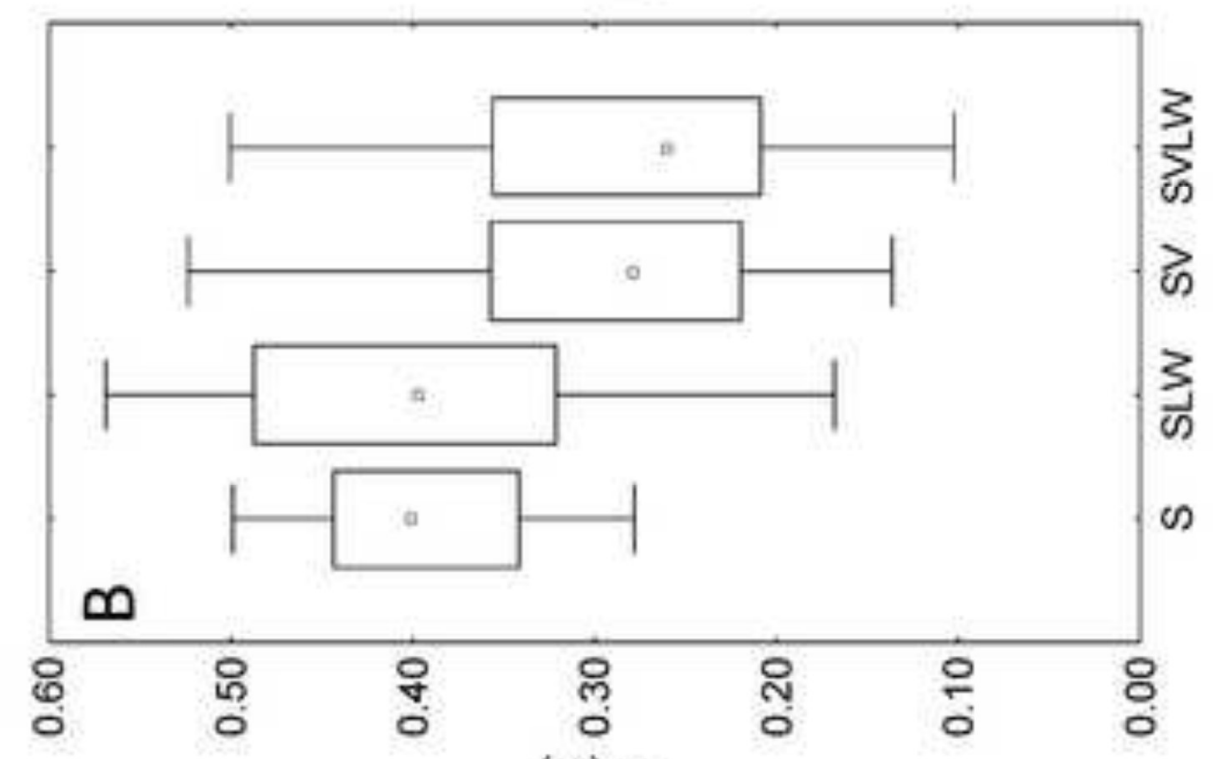

(\%) $M$

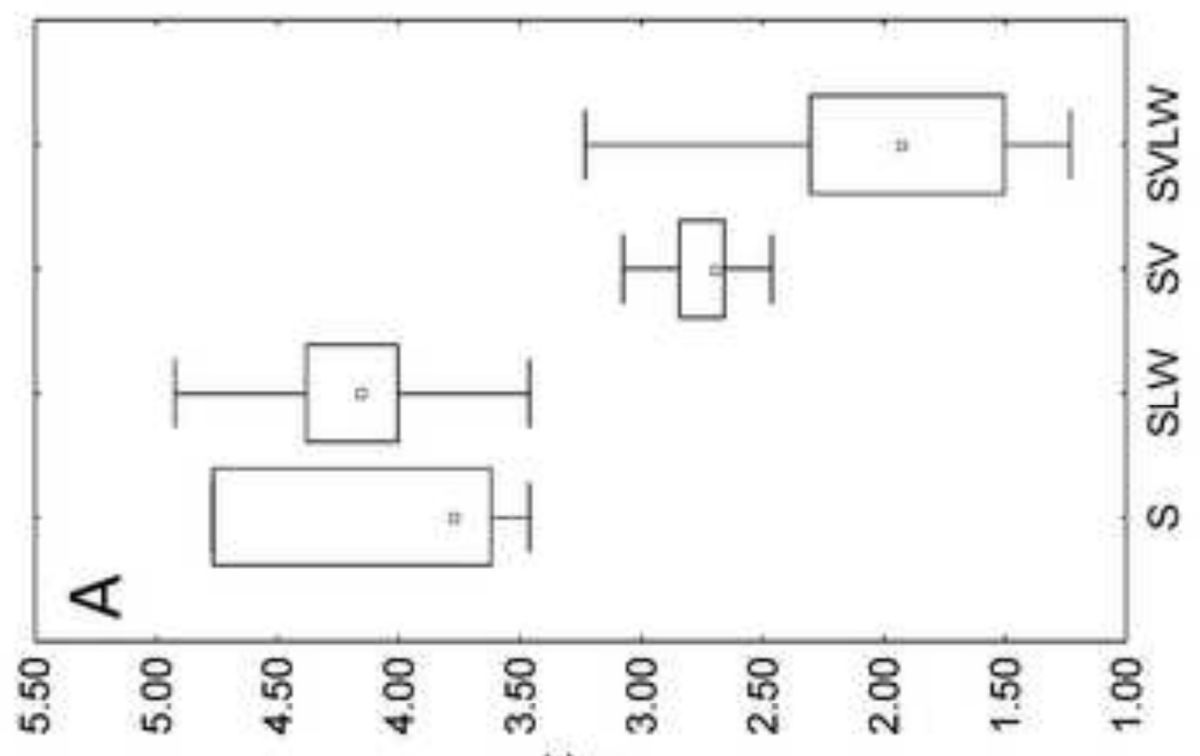

(-) 18 

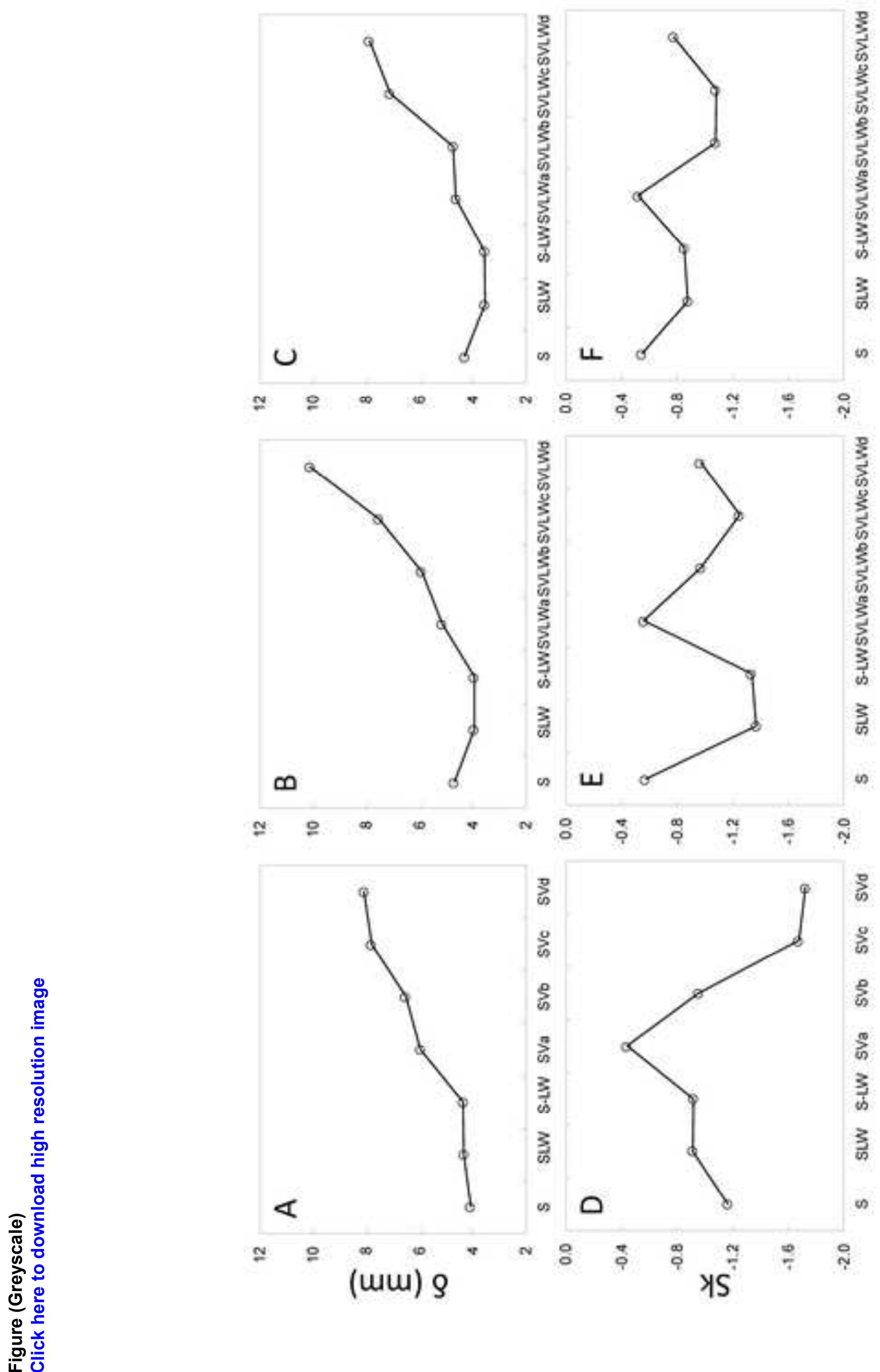


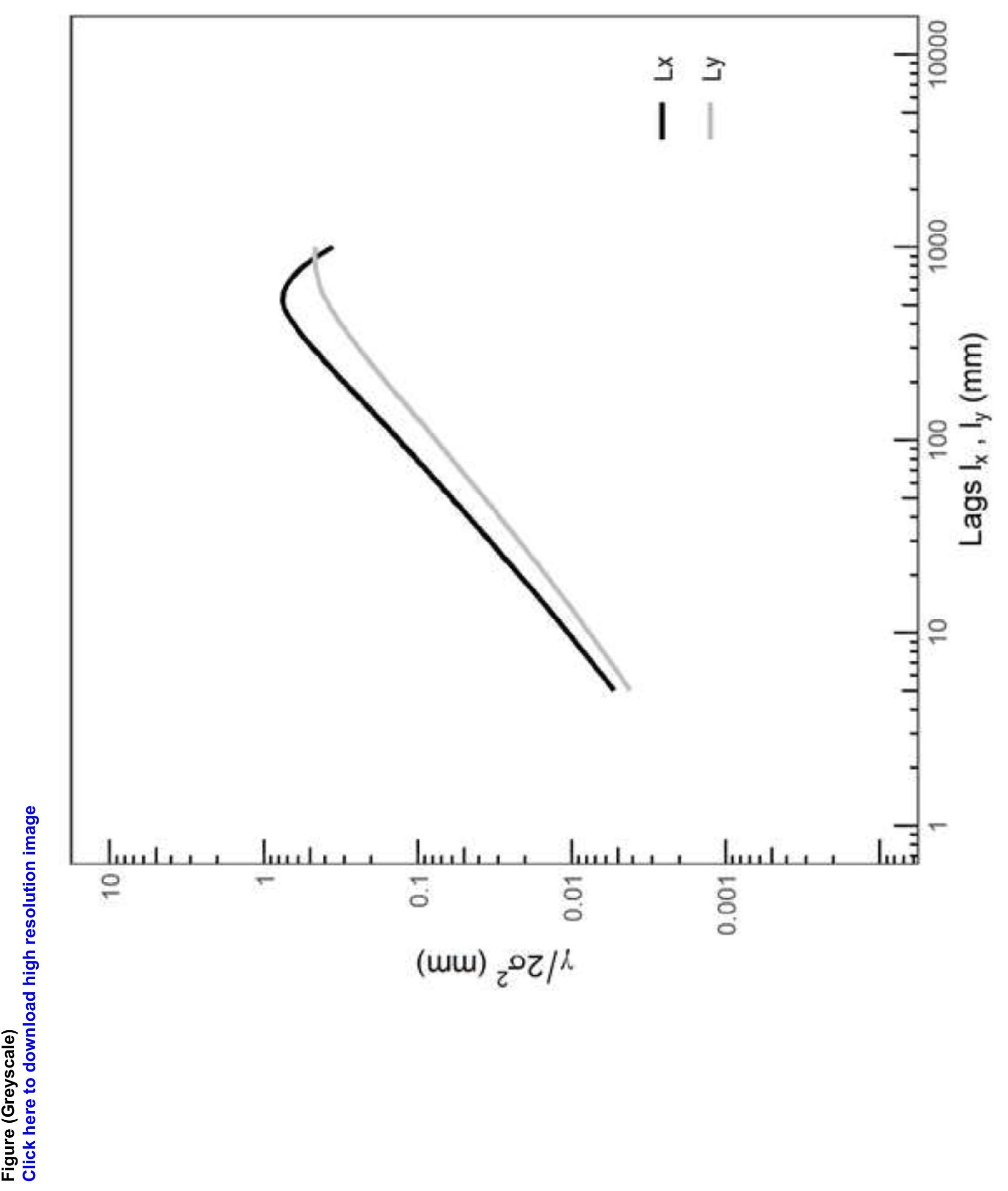



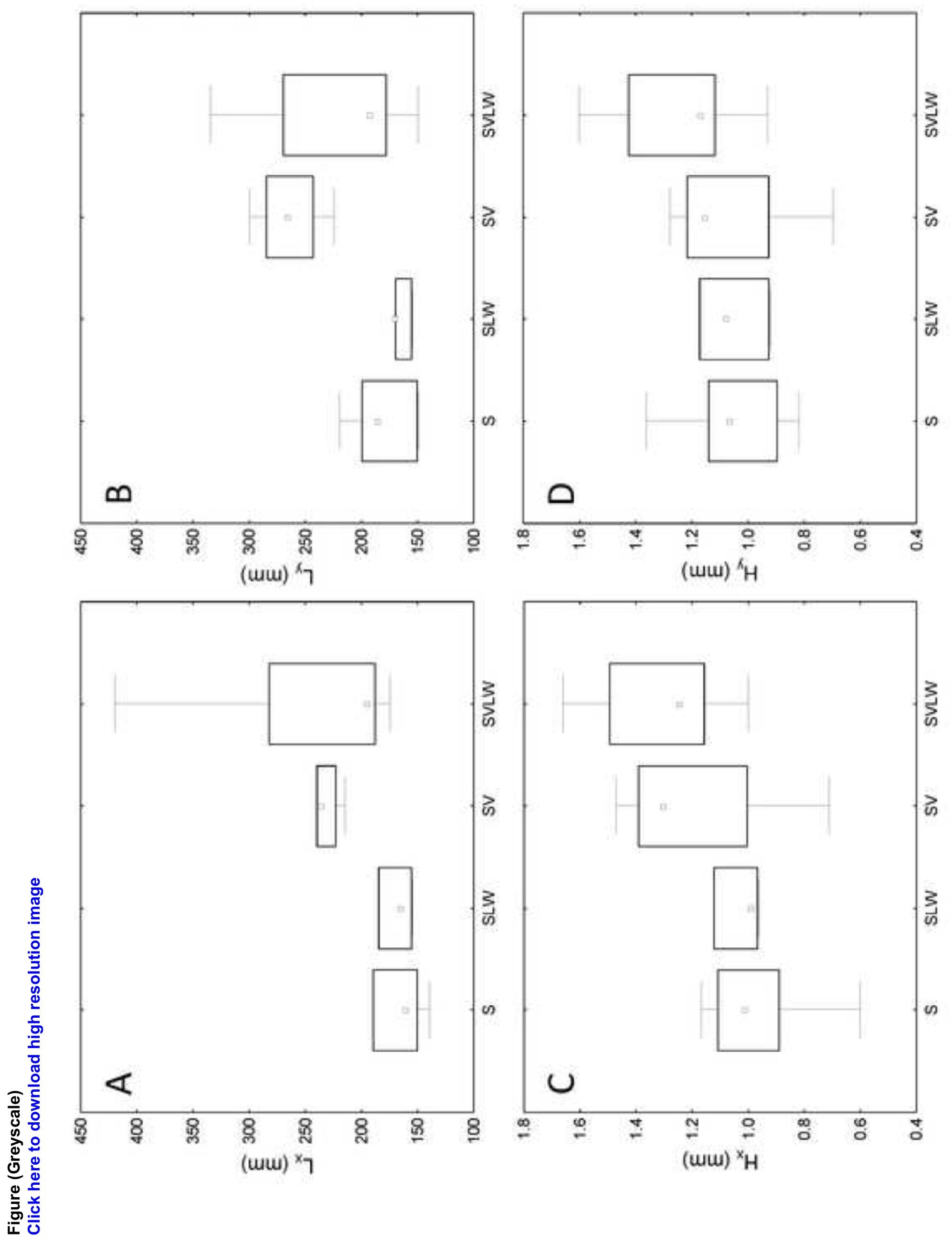